\title{
Can Europe Prosper Without the Common Currency? A Historical Perspective
}

\author{
Ton Notermans
}

\author{
Department of International Relations, Tallinn School of Economics and Business Administration, Tallinn \\ University of Technology, Estonia
}

\begin{abstract}
The Eurocrisis displays an astonishing similarity to the causes of the Great Depression in the form of massive current account imbalances, destabilising capital flows, financial fragility, and the commitment to defending a fixed exchange rate arrangement by means of austerity and internal devaluation. From the interwar economic and political disaster Europe eventually drew the lesson that internal balance had to enjoy priority over external balance, giving rise to a three-decade long period of unprecedented economic growth after the Second World War. As Europe has again stumbled into many of the policy errors that caused the Great Depression, it will need to relearn some of these lessons. In particular, the paper suggests that Europeanisation has gone too far and that rather than completing the monetary Union, Europe's prosperity and political stability would be better served by compartmentalisation of financial markets, vertical industrial policies and an escape clause in the common currency allowing for temporary exit in case of fundamental disequilibria.
\end{abstract}

Keywords: European Integration, Monetary Union, Eurozone, Economic History Europe.

\section{INTRODUCTION}

The political and economic dynamics of the Eurozone crisis has come to display astonishing parallels to the interwar Gold Standard (Eichengreen 2015; Eichengreen \& Temin 2010; O'Rourke \& Taylor 2013). Like the resurrection of Gold Standard in the mid-1920s, agreement on the introduction of a common currency was primarily driven by the desire to impose discipline on a political dynamics that seemed to drive escalating budget deficits and rampant inflation. Like the interwar Gold Standard, the Euro and the accompanying Single Market in Financial Services (SMFS), became an engine of asymmetric shocks by means of massive macroeconomic imbalances driven mainly by a rapid build-up in private debt in peripheral countries and fuelled by capital inflows from the core countries. Like the interwar Gold Standard, the attempt to defend the common currency by means of internal devaluation and austerity not only proved immensly costly in terms of growth and unemployment but also provoked political polarisation and extremism, thus placing the issue of the compatibility of capitalism and democracy again on the political agenda (Funke et al. 2015). As Bordo \& James (2013: 25) put it: "It is now clear that contemporary Europe is re-enacting the political economy logic of that interwar upheaval."

For the European Union institutions, as well as most scholars, the solution to the current problems of the common currency consists in a further deepening of

*Address of correspondence to this author at the Akadeemia Tee 3, 12618 Tallinn, Estonia, Tel: +372 620 4119; Fax: +372 420 3946;

E-mail: antonius.notermans@ttu.ee integration (E.g. Enderlein et al. 2012; Juncker 2015, Legrain 2014; Matthijs \& Blyth 2015; van Rompuy 2012). Some steps have already been taken on this road towards "completing the Euro" such as increased fiscal policy surveillance through the European semester, a strengthened Stability and Growth Pact (SGP), the introduction of the surveillance and resolution elements of the banking union, the creation of the European Fund for Strategic Investment (EFSI) and the decision of the European Central Bank (ECB) to equip itself with a lender of last resort function. Yet further steps are said to be needed. According to the 5 Presidents Report (Juncker 2015) three new unions are required. A financial union, involving the completion of the banking union with a common backstop plus the creation of a Capital Market Union (CMU), will promote investment lending and thus growth, and will avoid shouldering national authorities with having to address problems of what by now is a thoroughly Europeanised financial system (Juncker 2015: 11-129). A fiscal union, in turn will prevent national policies from creating externalities that threaten the Euro. Increasingly responsive to Keynesian demands for less austerity and more countercyclical spending, the 5 presidents also postulate the need to equip the EU with a fiscal capacity to address asymmetric shocks. (Juncker 2015: 8-9; Pasimeni 2014). Strengthening the economic union by removing the existing barriers in the single market and structural reforms will make European economies more resilient to shocks (Juncker 2015. 79). Finally, political union is assigned the role of providing the democratic legitimacy for these transfers of competences from the member states to the EU. 
Scaling back European integration instead is seen by the Brussels institutions, alongside the overwhelming majority of scholars, as a recipe for economic and political disaster, similar to the globalisation backslash that is seen to have stood at the roots of the Great Depression. Liberals tend to emphasise that a highly integrated world economy leaves no alternative to pursuing cost competitiveness in trade, especially in view of the ever larger share of manufacturing exports from emerging economies, while to maintain the confidence of footloose capital "sound" fiscal and monetary policies are required. The Left instead is more prone to argue that globalisation has irrevocably robbed the nation-state of any meaningful policy autonomy (Bofinger et al. 2012; Fratscher 2016; Habermas 2016). As a result, the only option available to the EU is a "Flucht nach vorn" by "completing" the monetary union.

Yet, the view that only further integration can cure Europe does not seem convincing. Kindleberger's (1986) view that a breakdown of international economic cooperation caused the Great Depression ${ }^{1}$ is no longer shared by most economic historians. The contraction in international trade, for example, is not nearly sufficient to account for the depth of the Great Depression (Bernstein 2008: 354). Instead, the causes of the Great Depression were rather similar to what caused the Eurocrisis. The core factors were massive and in part highly speculative international capital flows causing huge imbalances and sparking a recession in the wake of sudden stops; the Gold Standard itself which mandated tighter money, fiscal austerity and downward wage flexibility in order to defend the parity in the face of adverse capital flows thus turning the recession into a depression; and the emphasis on deflating the price level which threatened to given the downturn a cumulative character.

On the contrary, the globalisation backlash provoked by the Great Depression lay the foundations for the so-called Trente Glorieuses, during which West European economies not only grew at an unprecedented rate but capitalism was made compatible with democracy (Berman 2006; Ruggie 1982). Europe's post-war growth model established the primacy of politics over the currency, or in economist language, the primacy of internal over external balance, From now on the currency, international financial transactions, as well as trade could be

\footnotetext{
${ }^{1}$ Harold James (2016) still holds a similar view.
}

interfered with when in conflict with the requirements of internal balance while, if necessary, the parity would be adjusted to wage cost developments rather than the other way round. As a result, the so-called, Trente Glorieuses became the only monetary and financial regime in European history that managed to combine high growth, monetary and financial stability, low unemployment and social inclusion.

Because Europe has again stumbled into many of the policy errors that caused the Great Depression, it will need to relearn some of the lessons that episode had taught. Although history thus would suggest that scaling back rather than completing the Economic and Monetary Union (EMU) may provide a more promising route to renewed prosperity, it cannot automatically be assumed that the political foundations on which the post-war model rested can be recreated. In contrast to what seems to be the consensus view, the post-war growth model did not become undone because of globalisation. The boom ended as country after country switched to restrictive policies to stamp out what came to be known as the Great Inflation. The post-war social contract came apart for essentially political reasons as most governments found it impossible to contain distributional conflicts that gave rise to wage-driven inflation and escalating deficits, without the discipline of higher unemployment (Notermans 2000) ${ }^{2}$. The new (liberal) orthodoxy was not imposed by the dictates of globalised capital. Indeed, in the 1992-3 Exchange Rate Mechanism (ERM) crisis that same globalised capital forced several countries, such as Italy, into a devaluation with positive effects on growth. Instead, the opposite comes closer to the truth. Similar to the post 1918 inflation experience that can explain much of the decision to resurrect the Gold Standard and the tenacity with which governments clung to it, the breakdown of the post-war consensus gave rise to a policy regime in which governments sought to enlist the support of markets and European integration to force their economies into a rigid nominal framework.

In short, the question whether some EU member states would best be served by abandoning the common currency at heart is an issue in political economy. Though abandoning the common currency would provide member states with the leeway to address destabilising capital flows, as well as the possibility to orient monetary and exchange rate

${ }^{2}$ Collignon (2002) similarly attributes the decline of the post-war model to inflationary pressures. 
policies towards internal equilibrium, such policies can only succeed if the relaxation of external discipline on the political system does no reignite the distributional struggles that characterized the Great Inflation of the 1970s. Put differently, though adherence to a common currency has proven to be extremely costly in political and economic terms, the existence of a viable alternative will depend on the ability to construct a modern day equivalent of the social contract that underpinned Western Europe's highly successful economic policies during the first three decades following the Second World War.

The remainder of this paper is structured as follows. Section 2 argues that market fragmentation and policies of de-financialisation rather than financial union will most likely provide a sounder basis for a stable European economy. Section 3 argues that addressing the forces that hold back private investment by means of financial re-regulation, debt reduction, and an end to austerity are more urgent than the creation of an EU fiscal policy capacity to address asymmetric shocks. Section four claims that a vertical industrial policy is the most appropriate tool to address the structural weaknesses of the peripheral countries while completion of the single market and strengthening wage flexibility instead are apt to exacerbate problems of economic divergence and deflation. Section five argues that, in analogy with the Bretton Woods system, the common currency would need to be equipped with a safety valve allowing member states to temporarily exit in case of fundamental disequilibria. Section 6 concludes.

\section{FINANCIAL UNION: FRAGMENTATION FOR STABILITY}

Though commonly called the sovereign debt crisis or Eurocrisis, a better label would be the second financial crisis of the $21^{\text {st }}$ century. The term Eurocrisis is misleading as no run on the common currency occurred. In Spain, Ireland and Cyprus the crisis was sparked by excessive private debt, with the rapid increase in sovereign debt resulting from the bailout of the financial system. Indeed, in contrast to most other West European countries, in 2007 sovereign debt in Spain, Cyprus, and Ireland was well below the $60 \%$ level. The label sovereign debt crisis would seem more appropriate for Portugal and especially Greece. Both countries had run sizeable budget deficits already before the crisis, and while Portuguese gross public debt stood at $68 \%$ of GDP in 2007, it already exceed $100 \%$ in Greece. Though creditors in Europe, as in the numerous other financial crises that have occurred since the 1980s, sought to place the blame unilaterally on debtors, it takes two parties to create debt. The escalation of Greek debt only was possible because investors failed to undertake an adequate creditworthiness appraisal and instead accumulated highly risk positions in the confidence that a public bailout would be orchestrated if things should go wrong (Abelshauser 2010). Being able to borrow in Euros instead of the inflation and devaluation-prone Drachme gained Greece ample access to foreign funds, while prudential regulation imposing zero risk weights for sovereigns and the ECB 's insistence that all Eurozone sovereigns were equal in its efforts to create a SMFS, further promoted lending. Moreover, the no-bail out clause of the Maastricht Treaty lacked its logical corollary of a debt restructuring mechanism.

In short, the Eurocrisis first and foremost is an example of botched financial de- and re-regulation similar to e.g. the Nordic and Japanese financial crises of the early 1990s and the East Asian crisis of 1997 (Turner 2014). While the post-war orthodoxy saw capital account convertibility as a potential threat to the primacy of internal balance, as a result of the Great Inflation, policy-makers became more concerned with creating external constraints to foster domestic discipline. Accordingly, the member states managed to agree in 1985 on EU Directive 361/1988, which abolished all restrictions on intra-union capital flows. Simultaneously, boosting the financial services industry now came to be seen as crucial, not only because the industry itself was a potential growth sector but also because more competition, a more effective allocation of capital and a wider array of services were held to have significantly positive overall growth effects. Moreover, catching-up with, and possibly overtaking the US financial industry now became a prime driving force in the EU's financial market policies.

Already the 1985 White Paper advocated removing the (national) bulkheads that separated the various financial services industries - decompartmentalisation for short. The introduction of the Euro gave a major boost to financial integration. First, by removing exchange rate risk the common currency boosted cross-national capital flows. Secondly, the Euro placed the Single Market in Financial Services (SMFS) on the EU agenda. The SMFS, contained in the Commission's Financial Services Action plan of May 1999, envisaged 43 legislative measures to boost an integrated market in financial services. In part, the SMFS was an exercise in deregulation and negative integration that reduced 
the policy tools available to member states without recreating such tools at the EU level, principally through the mutual recognition principle in financial services. In part, the SMFS engaged in positive integration by creating some specific tools to promote financial services. During the first decade of the new millennium, the EU issued a set of directives that sought to promote trade in repos and derivatives through so-called safe harbour clauses that provided such instruments with special privileges such as exemption from stay in bankruptcy and cross-default clauses, again with the aim of capturing part of a market dominated by US firms (Perotti 2011). ${ }^{3}$

In sum, the outcome of domestic deregulation, the single market in financial services, and the Euro itself was not only a larger, more concentrated and more fragile financial system, but also the emergence of huge imbalances in which the Northwestern creditor countries engaged in financing asset- and consumption booms in the Eastern and Southern periphery. Indeed, as Merler (2015) has shown, the increasing divergence in financial cycles in the EU coincided with and was the result of financial and monetary integration. Financial fragility was by no means an issue of the GIPS (Greece-Ireland-Portugal-Spain) countries only. ${ }^{4}$ But while the creditor countries were able to orchestrate a politically highly unpopular bailout of the financial system with domestic funds, what turned financial fragility into a sovereign debt crisis were the large macroeconomic imbalances. Being unable to roll over its debt, Greece became dependent on EU assistance. Instead of organising another highly unpopular bailout of financial institutions, the EU solution involved an insistence on full repayment in exchange for temporary assistance. In Spain and Ireland instead, the sudden stop of capital inflows from North Western Europe meant that the decision to turn the private debt of the financial system into public debt provoked acute doubts about the sustainability of that debt, thus creating the need for foreign assistance.

Since financial and monetary integration itself, therefore, was a main cause of the Eurocrisis, one might question whether further integration of financial services serves the needs of a European Union in

\footnotetext{
${ }^{3}$ In particular: Financial Collateral Directive of 6 June 2002, EU Settlement Finality Directive of 19 May 1998, Directive 2009/44/EC of 6 May 2009 amending Directive 98/26/EC, and Directive 2002/47/EC.

${ }^{4}$ Maurer \& Grussenmeyer 2015. Moreover, the high cost of bank bailouts in Greece to a considerable extent is the result of adjustment policies that caused a rapid increase in non-performing loans as a result of the collapse of GDP.
}

which all member states can prosper. Yet, amongst the EU policy elites, the media and in academic circles there seems to be a virtual consensus that the crisis has demonstrated the need for further integration. The EU's first reaction to the financial crisis, the Banking Union, is not designed to reduce financial fragility but to break the so-called doom loop in which bank bailouts undermine the confidence in the sustainability of the public debt of peripheral countries while conversely the loss of confidence in public debt threatens to wipe out the assets of banks. To break this doom loop a single resolution mechanism and single resolution fund was required. This in turn would not be feasible without centralised supervision. Given the small size and the de facto national compartmentalisation of resolution funds, it is doubtful whether the current set-up of the Banking Union can indeed break the link between sovereigns and banks (Fazi \& lodice 2016). Even if political opposition could be overcome, the Banking Union does little to reduce financial fragility; the too-bigto-fail problem, if anything has become more acute. Modest proposals for a separation of investment and commercial banking have been blocked by Germany and France, and central clearing of derivatives rather creates an additional actor that is too-big-to-fail rather than reducing risk.

The EU's plan for a Capital Market Union (CMU) in turn, is likely to further increase financial fragility. ${ }^{5}$ The basic motivation for the CMU is to stimulate EU-wide capital markets given the impaired lending ability of the banking system. However, that solution ignores some of the main lesson of the financial crisis. The first lesson is that the originate-to-distribute model in which banks no longer hold on to the mortgages they originate, and which is an inherent element of derivatives trading, increases the overall risk exposure such that a reduction in the use of such models would seem advisable rather than its promotion as envisaged by the CMU. The second is that long intermediation chains and lack of transparency created financial institutions too interconnected to fail.

In contrast, the Trente Glorieuses stand out in financial history for their absence of financial crises. That stability was achieved via two different models with one common element. Between the financial reforms inspired by the Great Depression and their

\footnotetext{
${ }^{5}$ See e.g. the open letter to the European parliament https://crimfi.files.wordpress.com/2016/05/open-letter-to-meps-stssecuritisation.pdf
} 
gradual dismantlement since the 1980s, the US banking system was guided by the principle of small is beautiful. Not only did it foresee a horizontal compartmentalisation between investment banking and deposit taking institutions, interest rate caps and reduced competition, but the system also displayed an extreme geographic fragmentation via the interdiction on interstate banking and a highly varying patchwork of state-level banking regulation. In Europe, national level regulatory frameworks had a similar fragmenting effect as the US rules on interstate banking; while the potential fragility of the universal banking model was contained by tight financial repression allowing the authorities to directly intervene in the amount and type of lending undertaken.

The common element in both models was the discouragement of financialisation. In a financial system that serves the real economy by lending for productive purposes, debt and GDP should move more or less in tandem. The reforms undertaken in Europe and elsewhere have done nothing to promote definancialisation. As research by the MckInsey Global Institute (2015) has shown, debt to GDP ratios have continued to increase in all advanced economies since 2007. Accordingly, European economies have further moved into a speculative position, in the sense that an escalating debt to GDP ratio implies that income streams may not guarantee debt service such that debtors must speculate on favourable movements in asset prices for their position to be sustainable (Montanaro \& Tonveronachi 2012).

In sum, the historical record would suggest that rather than completing financial integration, economic stability and growth would best be served by fragmentation, financial repression, cartelisation and definancialisation. ${ }^{6}$ The ECB's standard argument that more financial integration is needed to restore the uniformity of the monetary transmission mechanism sounds odd given that its one-size-fits-all monetary policy, i.e. the creation of uniform lending conditions before the crisis, is recognised to have contributed to the subsequent imbalances. There is no convincing evidence that financial deregulation in any way has promoted growth (Cournède et al. 2015, Wyplosz 2010). Indeed, as Paul Volcker famously remarked in 2009, "The only useful thing banks have invented in 20 years is the ATM" ${ }^{\prime}$. Such policies would come at the

\footnotetext{
${ }^{6}$ For a similar view on global financial integration, see Bhagwati 1998. ${ }^{7}$ http://nypost.com/2009/12/13/the-only-thing-useful-banks-have-invented-in-20years-is-the-atm/
}

cost of giving up the attempt to create a globally competitive financial industry in Europe, but that is a price well worth paying for an economically and politically more stable continent.

\section{FISCAL UNION: PROMOTING INVESTMENT}

Much of the initial effort to repair the cracks in the Euro focused on centralising fiscal policy in order to eliminate the free-riding of national governments to which the incomplete supranationalisation of EMU allegedly gave rise. The fiscal compact sought to anchor a balanced budget rule in national legislation; better coordination of national budgets was to be achieved by the "European Semester", while a strengthened SGP should ensure that the excessive deficit procedure would be triggered almost automatically while providing a clear adjustment path. Nevertheless, the policy of debt reduction has spectacularly failed. With the exception of Germany, Malta and Latvia, public debt levels are higher in 2015 as they were in 2010 , while private debt build-up has continued unabated. ${ }^{8}$

As the crisis progressed, fiscal austerity alongside fiscal profligacy, came into focus as a problem that might require a supranational fix. The argument was not new as it followed from the short-term framework of Optimal Currency Area (OCA) theory. With monetary and exchange rate policies unavailable, asymmetric shocks would have to be addressed by fiscal policies. This implied that the SGP made EMU over-complete as national fiscal policies needed more leeway. Yet, the high level of public debt and the inability of some member countries to roll it over, suggested to many the need for a countercyclical facility at the EU level.

However, insurmountable political hurdles block the road to EU fiscal federalism. Proposals for an EU fiscal capacity, including Eurobonds, were already present in the van Rompuy Report (van Rompuy 2012). The former still is part of the 5 Presidents Report, though in a much watered down version due to the fear of the net contributors to the EU budget that an additional permanent transfer mechanism in favour of the periphery will be created. Accordingly, the five presidents argue that a fiscal capability should only be acquired once convergence and economic union is complete, and should not result in permanent transfers nor be used for crisis management.

${ }^{8}$ Source for public debt figures: AMECO. Source for total debt/GDP ratios: McKinsey Global Institute 2015: 3. 
Yet again, the historical record does not provide many indications that fiscal federalism might be able to put Europe back onto a growth path. Not only is it hard to detect Keynesian responses during the Great Depression, countercyclical demand management played at best a minor role in the Trente Glorieuses. Instead, growth was based on high levels of investment with little need for demand management. As Battilossi et al. (2010: 361) put it, "fluctuations in western European output and employment were so mild that the very notion of a "cycle" was transformed or even seemed obsolete". Similarly, after a careful examination of the postwar years, Bispham and Boltho (1982) failed to find much evidence for Keynesianism, ultimately embracing the position that the government's willingness to use such policies created the expectations that made them unnecessary.

Though several episodes of Keynesian demand management can be identified in the 1960s, it could well be argued that the age of Keynesian countercyclical policies only started in earnest in the 1970s, but there they proved ineffective in rekindling growth while boosting inflation. Indeed, the end of the Trente Glorieuses has given rise to almost permanent budget deficits in Western Europe in an attempt to shift some of the adjustment burdens of lower growth onto future generations ${ }^{9}$, but the one thing this continuous deficit spending has not done is to restart the growth engine.

The weakness of the call for a countercyclical fiscal capacity lies in a refusal to enquire into the causes of a downturn and in the assumption that consumption and investment are substitutable categories. Treatises expounding the Keynesian framework commonly start with an attack on Say's law, the alleged fallacy being that income does not necessarily need to be spent, thus leading to a shortfall in effective demand with equilibrium unemployment as a result (Davidson 2002). As a result, Keynesian remedies focus on stimulating demand instead of focussing direclty on investment. Apart from the fact that Say's law as such does not logically exclude the possibility of equilibrium unemployment because it simply implies that any level of supply is an equilibrium level, a focus on stimulating investment provides a more appropriate perspective on Europe's problems. A collapse in investment and not a jump in the propensity to save stands at the root of the

${ }^{9}$ France, e.g., recorded budget deficits in only three years between 1958 and 1971 , since the mid-1970s the budget has been permanently in deficit. current crisis. Deficit spending may be effective in stimulating growth when investment is held back by expectations of low demand and if it manages to convince investors that the increase in demand will be durable enough to warrant investment. If it does not do so, deficit spending will end by replacing investment spending with consumption while failing to reignite growth and most likely worsening the current account deficit. Indeed, the high levels of public debt that made EU fiscal federalism seem a more appropriate stabilization tool than increased budgetary leeway at the national level point to the historic ineffectiveness of deficit spending. ${ }^{10}$

Instead of boosting spending through an EU fiscal capacity, growth oriented policies should first and foremost seek to remove the factors that depress investment. ${ }^{11}$ This in turn would direct the focus to such issues as the need to address the large and growing debt overhang that serves to both reduce the incentive to borrow and the ability to lend; the set of financial regulations aimed at stimulating speculative instead of productive investment, the continued insistence on fiscal contraction, and the loss of competitiveness experienced by many peripheral EU economies, as well as the need for a growth oriented monetary policy.

\section{ECONOMIC UNION: DEFLATION AND DIVERGENCE}

Alongside austerity and tighter discipline on national fiscal policies, structural reforms are the main plank of the EU's current strategy. Though it is never spelled out exactly what structural reform entails, the main contention is that rigidities in product and labour markets account for much of the suboptimal performance of the periphery. The argument is politically expedient. It places the blame squarely on national governments, allowing the better-off EU members to ward off demands for more transfers, while it provides the EU with the argument that the removal of obstacles in the single market is essential for creating a genuine EMU (Juncker 2015: 7-9). Because political opposition to structural reforms is overcome more easily in times of crisis, it also provides an

\footnotetext{
${ }^{10}$ Another case in point is Japan where numerous deficit-spending programmes since the 1990 s have bloated gross public debt to over $240 \%$ of GDP while failing to reignite growth.

${ }^{11}$ In terms of factors depressing investment, Keynesians commonly do not go beyond a reference to an anthropological constant of animal spirits. The policy implication apparently being that there is not much to be purchased by enquiring into the effects of policy regimes on investment but that fiscal policies should simply run deficits until the bulls somehow get the better of the bears again.
} 
additional justification for austerity. After all, if serious structural reforms are crucial to the functioning of the common currency, and if such reforms require crisis conditions to be implemented, then a rapid recovery of the crisis countries would be inimical to the long term heath of EMU. ${ }^{12}$

That microeconomic rigidities must be the cause of disappointing performance was an almost inevitable conclusion of the economic policy philosophy that replaced the postwar orthodoxy, which concluded that macroeconomic policies had predominantly nominal and few, if any, real effects. Yet, the argument lacks macroeconomic foundation. Support for it comes from partial equilibrium models whereas in general equilibrium models price and quantity determination through the forces of demand and supply must be made inoperative for the conclusion of a Pareto optimal equilibrium to apply.

Moreover, empirical evidence for the benefits of structural reform is chequered. Structural rigidities first became a topic in the EU in the late 1970s and 1980s during the "eurosclerosis" debate. However, as Blanchard (2004) has shown, the increased unemployment of that period did not coincide with any notable proliferation of labour market rigidities. As most peripheral economies recorded above average growth rates in the wake of the introduction of the Euro, the problem appeared solved (Boeri \& Garibaldi 2009), yet it reappeared with full force after the onset of the crisis. Also in the Eurocrisis there is no good correlation between structural reforms and economic performance. The OECD's list of most reform friendly countries for the period 2007-14 is headed by Greece, followed by Portugal, Ireland and Spain. Iceland ranks last, while Luxembourg, Belgium, Germany and the Netherlands make up the four least reform-friendly EU countries (OECD 2015: 109).

The habit of European policy-makers to invoke structural rigidities in response to every macroeconomic crisis would suggest the victory of political expedience over evidence as it helps deflect the attention from the common currency. Instead of strengthening the Euro, forcing through labour market flexibilisation is apt to further increase the similarities between the Great Depression and the current crisis. As Irving Fisher (1933) has famously shown, the falling

\footnotetext{
${ }^{12}$ This is a constant theme in Wolfgang Schäubles speeches. See also Eichengreen 2015: 8.
}

price level imparted a cumulative character to the Great Depression as it increased real debt and defaults, reduced investment and increased unemployment while further weakening the banking system and undermining the propensity to consume. The prevalence of deflation explains why recovery from the Great Depression was promoted by the opposite of structural reforms, namely policies to strengthen the bargaining position of the trade unions and to put a floor under nominal wages, from the National Industrial Recovery Act (1933) in the USA, via the Matignon agreements (1936) in France, to the Dutch decision to make wage agreements binding on the entire industrial sector (1937) and the wage decrees of the NAZI board of Labour Trustees (1933) (Notermans 2000, Blyth 2013)

Though the Eurozone has been spared the deflation disease, the problem looms increasingly large on the horizon. The ECB's consumer price index has trended downward since October 2011 and has hovered between $-0.6 \%$ and $0.4 \%$ between January 2015 and September 2016. In the standard long-run neoclassical model, there is no link between labour markets and the price level as markets are assumed to only set relative prices. Though this so-called neoclassical dichotomy forms the backbone of the neutrality of money doctrine with which the ECB justifies it political independence, Mario Draghi, nevertheless, has recognized the problem when he explained in May of 2015 that "there were strong signs that the [downward] trend [of the price level] was being driven by weak aggregate demand. This was visible both at the macro level in a still wide output gap and a declining rate of core inflation; and at the micro level in subdued negotiated wages and low pricing power among firms." (Draghi 2015, emphasis in the original). In short, the insistence on more wage flexibility risks to amplify the crisis.

Similarly, the insistence on the need to complete the economic union in order to strengthen the common currency might further undermine the legitimacy of the EU to the extent that it exacerbates income divergence. The 5 Presidents are quite right to argue that "The notion of convergence is at the heart of our Economic Union" (Juncker 2015:7), given that EU and EMU membership in all peripheral members was supported by hopes of growing prosperity. They may be wrong though in arguing that a fully liberalised single market is the best way of bringing it about.

Table 1 takes a look at the development of relative purchasing-power-parity (PPP) per capita GDP in the 
Table 1: PPP Per Capita GDP Relative to EU(28) Average, in 2014 EKS Dollars (\%)

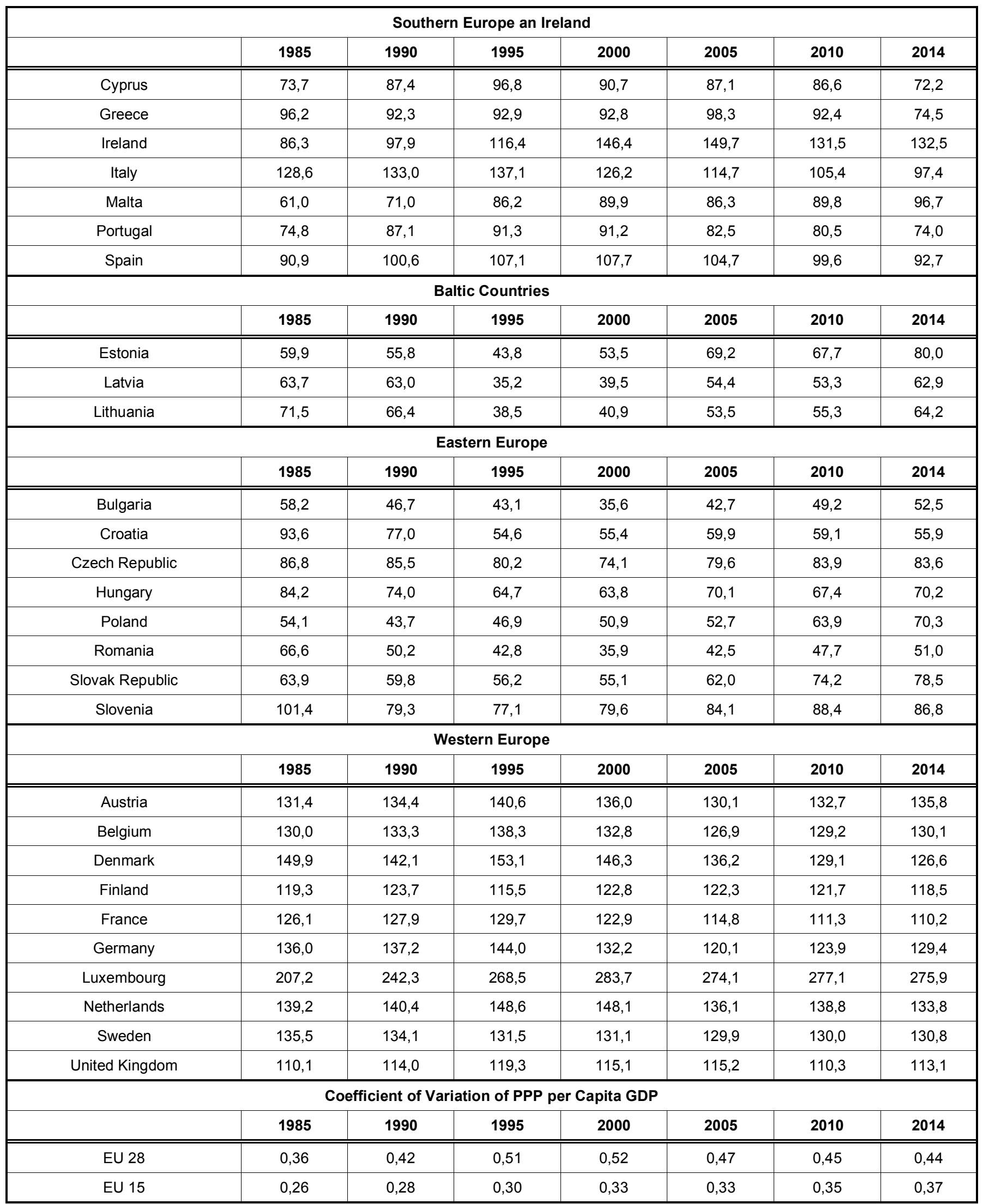

Source: The Conference Board Total Economy Database, own calculations. 
current members of the EU. Since the more commonly used Geary-Khamis method for calculating PPP overstates the income levels of poorer countries, Eltöto, Kovacs and Szulc (EKS) GDP per capita figures are used (Ackland, Dowrick \& Freyens 2013). As the coefficient of variation shows, in the EU(15), income disparities have increased since 1985. For the EU(28) the divergence trend was halted around the year 2000, with a slight decline since then, though disparities remain considerably wider within the $\mathrm{EU}(28)$ than the EU(15). Especially the five programme countries have been hit hard, while much of Eastern Europe is stuck in a middle-income trap.

As the experience of the successful East Asian developmental states would strongly suggest, a liberalised single market between countries at widely different levels of development tends to cement disparities due to first-mover effects resulting from learning curves and economies of scale. In Europe, the north-western manufacturing industry outsourced a considerable share of its low value added production to countries like Spain and Portugal. After the Eastern enlargement, some of this production moved Eastward thereby exacerbating structural problems in the South without setting the new member states on a path to convergence.

That trade integration does not solve problems of structural weakness but that an industrial policy is required was something the original six were well aware of. ${ }^{13}$ Unlike the current structural policies, the industrial policies of the Trente Glorieuses were not assigned the task of removing rigidities but aimed to increase productivity by upgrading the industrial structure. And unlike the EU's cohesion policies, which have a predominantly horizontal orientation, industrial policies are vertically oriented while the most successful ones use strict performance criteria.

Many of the traditional tools of industrial policy, like indicative planning, selective credit allocation and local content or technology transfer rules, might violate EU law, or at least stand in opposition to 'the spirit of completing EMU'. Yet the urgent need to strengthen the EU's legitimacy would suggest that, also in this case, promoting prosperity should take precedence over promoting integration as an end in itself by mitigating the level-playing field principle which

\footnotetext{
${ }^{13}$ Mazzucato (2013) shows that the USA continues to pursue a successful industrial policy
}

essentially forbids interventions to promote national industries, ${ }^{14}$ and by a reorientation of cohesion policies (Notermans 2016).

Moreover, the EU might play a critical role in solving the Achilles heel of industrial policy, namely close links between the government and industry leading to allocation of support on clientelistic principles while doing little to promote convergence. Especially in view of the corporate state capture that plagues many East European countries (Innes 2014), the EU might be essential in ensuring successful implementation. Though this might also result in the EU overriding decision of national institutions, a policy that provides tangible result might strengthen output legitimacy by confronting corrupted national elites.

\section{MONETARY UNION: FLEXIBILITY FOR GROWTH}

Though EMU was designed to be irreversible, monetary unions can be dissolved. Tepper's (2012) analysis of 69 breakups during the last century shows that the mechanism for and orderly dissolution are well known. One of the main arguments for doing so currently is that the Euro prevents differential wage growth from being corrected (Johnston \& Regan 2016). In theory, the issue could be addressed by further liberalisation of wage setting in the periphery. Alternatively, a rule requiring member states to keep their nominal unit labour costs (NULC) in line could be incorporated into EMU, as Flassbeck and Lapvitsas (2015) propose. However, apart from the high political and economic costs it would entail, fully flexible wages in slack labour markets promote deflation. Having the authorities at the central level determine wage growth, moreover, is politically infeasible because of opposition of the surplus countries as well as the labour market parties as it implies rendering unions and employers' associations irrelevant.

Table 2 lists labour costs, export volumes and real GDP for 13 Eurozone countries plus Sweden. Developments up to 2008 do lend some support to the contention that North European countries engaged in real devaluation as they generally record lower labour cost increases. However, France with a relatively fragmented industrial relation system performed better than traditionally corporatist countries such as the Netherlands and Sweden. While Luxembourg and

\footnotetext{
${ }^{14}$ That would be possible under articles 27 and 107.3(a) of the Treaty on the Functioning of the European Union.
} 
Table 2: Unit Labour Costs, Exports and GDP (1998 = 100)

\begin{tabular}{|c|c|c|c|c|c|c|c|c|}
\hline \multirow{2}{*}{} & \multicolumn{2}{|c|}{ NULC } & \multicolumn{2}{c|}{ NULC, Manufacturing } & \multicolumn{2}{c|}{ Export Volume } & \multicolumn{2}{c|}{ Real GDP } \\
\cline { 2 - 8 } & $\mathbf{2 0 0 8}$ & $\mathbf{2 0 1 5}$ & $\mathbf{2 0 0 8}$ & $\mathbf{2 0 1 5}$ & $\mathbf{2 0 0 8}$ & $\mathbf{2 0 1 5}$ & $\mathbf{2 0 0 8}$ & $\mathbf{2 0 1 5}$ \\
\hline \hline Germany & 102,1 & 118,2 & 92,5 & 98,7 & 200,3 & 243,7 & 116,9 & 123,9 \\
\hline Austria & 110,6 & 128,0 & 92,3 & 100,9 & 182,6 & 199,2 & 126,8 & 130,8 \\
\hline Finland & 116,7 & 138,8 & 78,0 & 99,9 & 199,5 & 176,1 & 138,2 & 130,8 \\
\hline Belgium & 119,3 & 132,2 & 96,8 & 97,7 & 157,4 & 189,0 & 125,4 & 131,8 \\
\hline Euro area & 119,6 & 130,7 & 101,7 & 106,3 & 171,2 & 203,7 & 123,3 & 123,7 \\
\hline France & 119,8 & 133,0 & 98,0 & 97,5 & 145,6 & 170,3 & 122,4 & 126,4 \\
\hline Netherlands & 123,8 & 136,7 & 99,4 & 106,1 & 168,4 & 205,6 & 127,8 & 128,5 \\
\hline Sweden & 123,8 & 141,7 & 89,3 & 92,7 & 174,0 & 194,1 & 134,2 & 148,8 \\
\hline Portugal & 129,1 & 124,6 & 110,3 & 109,4 & 154,4 & 196,5 & 117,4 & 110,7 \\
\hline Italy & 130,0 & 142,9 & 120,5 & 132,7 & 133,5 & 142,5 & 113,0 & 104,8 \\
\hline Cyprus & 136,2 & 134,7 & NA & NA & 119,4 & 126,9 & 150,3 & 136,2 \\
\hline Luxembourg & 137,2 & 159,0 & 149,2 & 166,9 & 217,2 & 267,1 & 153,6 & 177,9 \\
\hline Spain & 139,7 & 133,3 & 123,7 & 117,4 & 155,0 & 189,2 & 142,1 & 135,9 \\
\hline Ireland & 140,3 & 112,3 & 100,4 & 50,4 & 215,6 & 309,5 & 173,2 & 194,0 \\
\hline Greece & 143,0 & 135,6 & 114,9 & 107,7 & 206,6 & 188,7 & 140,9 & 104,4 \\
\hline
\end{tabular}

Source: AMECO, OECD, own calculations.

Ireland performed worse than a focus on their bargaining systems would have suggested. More important perhaps, there is no robust correlation between labour costs and export volume. Though negatively correlated, the $\mathrm{R}^{2}$ between increases in NULC and export volumes in the period 1998-2008 is close to zero. Nor do labour cost increases in manufacturing show the expected effect on export volumes. For the period 1998-2008 they are in fact slightly positively correlated (0.052) with an $\mathrm{R}^{2}$ of 0.001 . German exports doubled between 1998 and 2008 but the country is outperformed by Luxembourg, Ireland and Greece, three countries ranking towards the bottom of the list in terms of labour costs. Moreover, the five countries with the highest wage growth are also those with the highest GDP growth. These facts sit uneasily with the scenario of German hypercompetitiveness driving Southern Europe into crisis. Instead, they suggest that the imbalances created in the wake of the common currency, which in many cases drove a hypertrophy of the sheltered sector, fuelled much of the wage growth in the periphery. ${ }^{15}$

The costs of the Euro thus derive primarily from macroeconomic imbalances in combination with an

\footnotetext{
${ }^{15}$ Hopkin (2015) provides an interpretation of the Spanish and Italian cases along these lines.
}

asymmetric and highly restrictive adjustment strategy. Internal devaluation, austerity, structural reform and the insistence that debts be paid in full, perpetuated the crisis, made sovereign debt reduction illusory, while undermining long run growth prospects as much of the remaining industrial structure in countries such a Greece was destroyed while many young people with an appropriate education and language skills moved elsewhere. That it is possible even in today's Europe to cushion the cost of adjustment via the exchange rate has been demonstrated by the UK, Sweden, but especially Iceland. The IMF-led strategy in Iceland involved partial default on bank liabilities, combined with modest fiscal austerity, a substantial devaluation and exchange controls (IMF 2012). Though the liabilities of the Icelandic banking system amounted to roughly 10 times GDP at the onset of the crisis in 2007, the country has weathered the crisis better than the EU periphery in terms of GDP, public debt and unemployment. Only Irish GDP has shown a similar recovery though this was bought with the highest increase in total debt to GDP ratios of all OECD economies. In addition to financial reforms that prevent imbalances from occurring, this suggests that the EU could have spared itself much of the economic costs, the political polarisation and loss of legitimacy if EMU, in analogy with the Bretton Woods system, had included an escape clause providing for temporary exit 
in the case of fundamental disequilibria together with a mechanism for restructuring public and private debt. ${ }^{16}$

Competitiveness is a relative term such that a devaluation in the periphery would come at the expense of the surplus countries. Though such zerosum policies may be justified by the need to redress the damage done by the adjustment strategy, in analogy to the effects of the breakup of the interwar Gold Standard, (Temin 1989; Eichengreen \& Temin 2010; O'Rourke \& Taylor 2013) a dissolution of the Euro will promote overall growth in that it reduces the need for austerity and mitigates the deflationary bias resulting from the mercantilist low growth policies of Germany in particular (Micossi 2016). As the fate of the Macroeconomic Imbalances Procedure shows, attempts to provide the Euro with a symmetric balance of payments adjustment mechanism will falter on opposition of the surplus countries. Indeed, if the German government were to agree to abandon its Stabiltätskultur for the sake of Europe this would further promote the growth of anti-EU parties and undermine support for Europe within the political mainstream as well. Instead, a more flexible exchange rate system would no longer allow Germany to externalise its internal contradictions to Europe, but would force the domestic political system to address the choice between an overly restrictive policy orientation and the desire to prevent real appreciation in order to protect its current account surplus. Devaluation of a currency that exits the Euro would, of course, proportionally increase the real value of Euro denominated debt, and would make debt restructuring, which the IMF holds necessary in any case for Greece, even more urgent. But to the extent that it imparts a growth impulse it is likely to put downward pressure on sovereign debt interest rate differentials as it makes repayment of the remaining debt more likely.

However, adoption of the Euro in most Southern countries principally served the goal of restoring domestic political coherence in a system riven by distributional struggles. Abandoning the Euro anchor thus might carry the risk of promoting a cumulative loss of trust in the currency instead of strengthening it. Continued popular support for the Euro in even the

\footnotetext{
${ }^{16}$ Having the ECB buy part of the bad debts that are laming the financial system would currently seem the least costly road towards debt restructuring. The argument that debt forgiveness for e.g. Greece would create a moral hazard on the borrower side as such is not convincing because the insistence that all debts are paid in full creates a moral hazard problem on the lender side.
}

hardest hit southern member states largely reflects popular distrust in the ability of national governments to effectively manage the economy on their own. A devaluation induced wage-price-wage spiral would seem a remote possibility in the current deflationary constellation, but promoting growth under an independent currency would require a high degree of national consensus on the priority to channel resources to private sector recovery. Though it would remove the immediate pressures for austerity, many of the sacrifices made during the crisis could not be undone. Greece may not be Iceland and an unconstrained Greek government may be unable to ward off requests for rent seeking and unproductive spending leading to a scenario of further economic destabilisation.

In short, the challenge is to design a system in which the anchor function of the common currency can be combined with the need to adjust the exchange rate in case of fundamental disequilibria such that EMU could function as the contingent commitment of the pre-1914 Gold Standard in which abandoning the parity most commonly gave rise to stabilising instead of destabilising capital movements (Bordo \& James 2013; Bordo \& Kydland 1999). Wolfgang Schäuble's proposal of temporary Euro exit might provide a remedy as it could enlist the distrust in the national political class and the consequent support for European rules to promote a policy of economic recovery. The recognition that several South European economies suffer from a fundamental disequilibrium that will require devaluation together with clear criteria for a reintegration of the devalued currency in terms of a sufficient growth rate of GDP and exports might invert the growth depressing effects of the current regime while setting a clear objective that would serve to maintain domestic political coherence.

\section{AN OUTCOME-ORIENTED AND DIFFERE- NTIATED UNION}

Because the markets' reaction to the reintroduction of national currencies crucially depends on the political conditions in the exiting country, the question of whether the crisis countries would be better served by abandoning the common currency is an issue of political economy that cannot be answered by a simple balancing of economic costs and benefits. On the one hand, the above comparison with the interwar period and the Trente Glorieuses would suggest that abandoning the common currency plus a weakening of the single market would overall have economic advantages. While being nailed to a cross of gold in the 
Great Depression the crisis countries currently seem nailed to the Euro-cross. Devaluation of a reintroduced national currency, similar to the exit from the interwar Gold Standard, would not only give an immediate boost to growth, but would also lift the expectations of more decades of austerity to come. While sovereign debt levels are clearly unsustainable in Greece, making a (partial) default inevitable, rekindled growth will allow for debt reduction with less austerity. Moreover, as the remarkable financial stability of the postwar decades suggests, Europe is in need of more fragmented rather than more integrated financial markets. Finally, the large differences in GDP per capita, again in analogy to the Trente Glorieuses, suggest the need for a form of differentiated integration that allows the periphery to compensate for its relative underdevelopment with various forms of vertical industrial policies.

However, it is the political conditions under which such policies are pursued that will ultimately determine their effects. Rather than restoring confidence, devaluation of a newly introduced currency may be seen by markets as a signal of further devaluation to come, thus giving rise to destabilising capital flows. Similarly, a partial debt default may be interpreted as increasing the likelihood of further defaults rather than as a return to sustainable debt levels, again provoking a flight out of the currency. Differentiated integration that allows countries more leeway from the constraint of the single market, in turn may be interpreted by the markets as opening the door to fiscal mismanagement.

As argued above, it is the presence and strength of a broad political consensus in favour of inclusive growth, with the concomitant absence of virulent distributional conflict that will determine whether abandoning the Euro will mark the beginning of a durable recovery or the start of further dislocations. Though it is difficult to predict with any precision how Europe's periphery would fare in this respect, the long history of political fragmentation in Southern Europe and the current political polarisation would suggest that EU assistance would be needed by means of a form of integration that is more similar to the early decades of the EU in that it sought to accommodate the varying needs of the member states.

That early form of integration came apart with the disintegration of the post-war consensus in the 1970s. Instead, monetary integration came to impose the external constraint of irrevocably fixed currencies under central banks that had shed responsibility for growth while being accompanied by pressures for market conform structural reforms and containment of public debt. That model served the needs of those countries increasingly plagued by political fragmentation, labour militancy and a sum of claims on the national product that far exceeded the total. By serving as a political scapegoat while holding out the promise of prosperity and modernisation, tighter integration simultaneously furnished a shared goal and a set of constraints that provided for the second rescue of the nation state. At the same time, it allowed the Northern member states to execute the export-led growth model that had come to give coherence to their polities after a less severe crisis of governability in the seventies.

Yet, the same rescue of the nation state has sown the seeds of the union's demise. Ever tighter economic integration became an end instead of a means, thereby losing sight of the fact that Europe can only survive if it provides economic prosperity. Removing much of the remaining obstacles to the single market may have increased the discipline exerted over the member states but it came at a price of promoting economic divergence. Fixed exchange rates and capital account convertibility were intended to strengthen market discipline over individual economies, but in combination with a deregulation of financial markets, they became a recipe for imbalances and crises.

Combating the crisis by adherence to a fixed exchange rate and the attempt to further increase market pressures in the "deviant" southern economies through structural reforms might have made sense in a 1970s environment in which inflation, public spending and wage and price-setting were out of control, in the Eurocrisis it became a recipe for a further intensification of already acute problems. The issue thus is not simply one of Europe being too diverse for the straight jacket of common rules but just as much a problem of the straightjacket of EMU and single market in financial services themselves creating economic and political polarisation.

It took the combined shocks of the Great Depression, the interwar political polarisation and the Second World War, together with the systemic competition with the Soviet Union to lead European governments to the realisation that capitalism and democracy can only be made compatible if inequality is kept at tolerable levels by providing jobs and welfare. As this lesson was unlearned, the form of European integration that had served to cement this return to the Pre-Great Depression capitalism inevitably saw its legitimacy fade away. Anti-EU parties are making rapid 
electoral progress throughout the entire Union, from the Finns Party to the Alternative für Deutschland (AfD) and the Movimento Cinque Selle (M5S), while in Poland and Hungary anti-democratic nationalists have managed to secure a foothold. Though an increasingly embattled Commission sees itself forced to concede to more differentiated forms of integration, there are precious few signs that the lessons from a previous period are being relearned. The fear of operating without a constraint keeps the southern member states in the Euro. Financial reform is still firmly set on a path to more integration, more interconnectedness and more fragility and while the SGP and structural reform might become increasingly difficult to enforce, neither the political will nor the institutional capacity for a meaningful industrial policy is present. With an outcome oriented EU that takes a pragmatic approach to integration for the sake of economic prosperity, social inclusion and, in the end, political stability nowhere on the horizon, European prospects look bleak. In the end it might take a shock similar to the interwar period of escalating polarisation within and between European countries for the EU to rediscover its original purpose.

\section{REFERENCES}

Abelshauser, Werner (2010), "Die Erblast des Euro - Eine kurze Geschichte der Europäischen Währungsunion", Aus Politik und Zeitgeschichte 43: 39-45.

Ackland, Robert, Steve Dowrick \& Benoit Freyens (2013), "Measuring Global Poverty: Why PPP Methods Matter." The Review of Economics and Statistics, 95(3): 813-824. https://doi.org/10.1162/REST a 00294

Battilossi, Stefano, James Foreman-Peck \& Gerhard Kling (2010), "Business Cycles and Economic Policy, 1945-2007" In: Stephen Broadberry \& Kevin H. O'Rourke, eds., The Cambridge Economic History of Modern Europe Volume 2: 1870 to the Present. Cambridge. Cambridge University Press. https://doi.org/10.1017/cbo9780511794841.016

Berman, Sheri (2006), The Primacy of Politics. Cambridge: Cambridge University Press. https://doi.org/10.1017/CBO9780511791109

Bernstein, William (2008), A Splendid Exchange. London: Atlantic Books.

Bispham, John, \& Andrea Boltho (1982), "Demand Management." In Andrea Boltho, ed., The European Economy: Growth and Crisis. Oxford: Oxford University Press.

Blanchard, Olivier (2004), "The Economic Future of Europe." The Journal of Economic Perspectives 18(4): 3-26. https://doi.org/10.1257/0895330042632735

Blyth, Mark (2013), Austerity. The History of a Dangerous Idea, Oxford: Oxford University Press.

Boeri, Tito \& Pietro Garibaldi (2009), "Beyond Eurosclerosis", Economic Policy, July 2009: 410 - 461. https://doi.org/10.1111/j.1468-0327.2009.00225.x

Bofinger, Peter, Jürgen Habermas \& Julian Nida-Rümelin (2012), "Einspruch gegen die Fassadendemokratie" Frankfurter Allgemeine Zeitung, August 8.
Bordo Michael D. \& Finn E. Kydland (1999), "The Gold Standard as a Commitment Mechanism", In: Michael D. Bordo, The Gold Standard and Related Regimes: Collected Essays. Cambridge: Cambridge University Press. https://doi.org/10.1017/CBO9780511559624

Bordo, Michael D. \& Harold James (2013), "The European Crisis in the Context of the History of Previous Financial Crises", NBER Working Paper 19112. Cambridge MA: NBER.

Collignon, Stefan (2002), Monetary Stability in Europe. London: Routledge. https://doi.org/10.4324/9780203165928

Cournède, Boris, Oliver Denk, Peter Hoeller (2015). "Finance and Inclusive Growth", OECD Economic Policy Paper, June 2015 No. 14, Paris: OECD. https://doi.org/10.1787/5js06pbhf28s-en

Davidson Paul (2002), Financial Markets, Money and the Real World. Cheltenham: Edward Elgar.

Draghi, Mario (2015), The ECB's Recent Monetary Policy Measures: Effectiveness and Challenges; Camdessus Lecture by Mario Draghi, President of the ECB, IMF, Washington, DC, 14 May 2015.

Eichengreen, Barry (2015), Hall of Mirrors. Oxford: Oxford University Press.

Eichengreen, Barry \& Peter Temin (2010), "Fetters of Gold and Paper." Oxford Review of Economic Policy, 26(3): 370 - 384 https://doi.org/10.1093/oxrep/grq018

Enderlein, Hendrik, et al. (2012), "Completing the Euro," Notre Europe Studies \& Reports 92. Paris: Notre Europe.

Fazi, Thomas \& Guido lodice (2016), Why further Integration is the Wrong Answer to the EMU's Problems: The Case for a Decentralized Fiscal Stimulus.

Fisher, Irving (1933), "The Debt-Deflation Theory of Great Depressions," Econometrica 1 (4): 337 - 57. https://doi.org/10.2307/1907327

Flassbeck, Heiner \& Costas Lapavitsas (2015), Against the Troika. London: Verso.

Fratscher, Marcel (2016), Mißbrauch der Globalisierung, Berlin: Deutsches Institut für Wirtschaftsforschung,

Funke, Manuel, Moritz Schularick \& Christoph Trebesch (2015) "Going to Extremes: Politics after Financial Crisis, 18702014", CESIFO Working Paper NO. 5553, Munich: Centre for Economic Studies \& IFO Institute.

Habermas, Jürgen (2016), "Die Spieler treten ab.", Die Zeit, July 6 , 2016.

Hopkin, Jonathan (2015), "The Troubled Southern Periphery", In: Matthias Mathijs \& Mark Blyth, eds., (2015), The Future of the Euro. Oxford: Oxford University Press. https://doi.org/10.1093/acprof:oso/9780190233235.003.0008

Innes, Abby (2014), "The Political Economy of State Capture in Central Europe", Journal of Common Market Studies, 52(1): 88-104. https://doi.org/10.1111/jcms.12079

James, Harold (2016), "Es endet oft in Gewalt", Die Zeit, December 1, 2016.

Johnston, Alison \& Aidan Regan (2016) "European Monetary Integration and the Incompatibility of National Varieties of Capitalism", Journal of Common Market Studies 54(2): 318336. https://doi.org/10.1111/jcms.12289

Juncker, Jean-Claude (2015), Completing Europe's Economic and Monetary Union. Brussels: EU.

Kindleberger Charles (1986), The World in Depression. Berkeley: The University of California Press.

Legrain, Philippe (2014), How to Finish the Euro House. London: Centre for European Reform.

Matthijs, Matthias \& Mark Blyth, eds., (2015), The Future of the Euro. Oxford: Oxford University Press 
Maurer, Henri \& Patrick Grussenmeyer (2015), "Financial Assistance Measures in the Euro Area from 2008 to 2013: Statistical Framework and Fiscal Impact", ECB Statistics Paper 7 / April 2015. Frankfurt /Main: ECB.

Mazzucato, Mariana (2013), The Entrepreneurial State London: Anthem Press.

Mckinsey Global Institute (2015), Debt and (not much) Deleveraging. London: Mckinsey Global Institute.

Merler, Silvia (2015), "Squaring the Cycle: Financial Cycles, Capital Flows and Macroprudential Policy in the Euro Area", Bruegel Working Paper 2015/14. Brussels: Bruegel.

Micossi, Stefano (2016), "Balance-of-Payments Adjustment in the Eurozone", LUISS School of European Political Economy Policy Brief, January 21.

Montanaro, Elisabetta \& Mario Tonveronachi (2012), "Financial reregulation at a Crossroads: How the European Experience Strengthens the Case for a Radical Reform Built on Minsky's Approach", PSL Quarterly Review, 65(263): 335 - 383.

Notermans, Ton (2000), Money, Markets, and the State. Cambridge: Cambridge University Press. https://doi.org/10.1017/CBO9780511521607

Notermans, Ton (2016), "Does Cohesion Policy Lead to Economic Convergence?", in: Simona Piattoni \& Laura Polverari, eds., Handbook of Cohesion Policy in the EU. Cheltenham, UK: Edward Elgar, pp. 461 - 474 https://doi.org/10.4337/9781784715670.00046
O'Rourke, Kevin H. \& Alan M. Taylor (2013), "Cross of Euros", Journal of Economic Perspectives, 27(3): 167 - 192. https://doi.org/10.1257/jep.27.3.167

OECD (2015), Economic Policy Reforms: Going for Growth. Paris: OECD.

Perotti, Enrico (2011), 'Systemic Liquidity Risk and Bankruptcy Exceptions', CEPR Policy Insight No. 52. London: CEPR.

Ruggie, John Gerard (1982), "International Regimes, Transactions, and Change: Embedded Liberalism in the Postwar Economic Order", International Organization 36(2): 379 - 415. https://doi.org/10.1017/S0020818300018993

Temin, Peter (1989), Lessons from the Great Depression. Cambridge MA: The MIT Press.

Tepper, Jonathan (2012), A Primer on the Euro Breakup: Depart, Default and Devalue as the Optimal Solution. A Submission for the Wolfson Economics Prize 2012.

Turner, Adair (2014), "Something Old and Something New: Novel and Familiar Drivers of the Latest Crisis", In: Piet Clement, Harold James \& Herman Van der Wee, eds., Financial Innovation, Regulation and Crises in History, London: Pickering \& Chatto.

van Rompuy, Herman (2012), Towards a Genuine Economic and Monetary Union. Brussels: EU.

Wyplosz, Charles (2010), "Financial Restraints and Liberalization in Postwar Europe", In Gerard Caprio, Patrick Honohan \& Joseph Stiglitz, eds., Financial Liberalization: How Far, How Fast? Cambridge: Cambridge University Press.

DOI: https://doi.org/10.6000/1929-7092.2017.06.11

(C) 2017 Ton Notermans; Licensee Lifescience Global.

This is an open access article licensed under the terms of the Creative Commons Attribution Non-Commercial License (http://creativecommons.org/licenses/by-nc/3.0/) which permits unrestricted, non-commercial use, distribution and reproduction in any medium, provided the work is properly cited. 